\title{
The Dual Legality of the Rules of International Organizations
}

\author{
Lorenzo Gasbarri* \\ lorenzo.gasbarri@graduateinstitute.ch
}

\begin{abstract}
This paper examines the legal nature of the 'rules of international organizations' as defined by the International Law Commission in its works on the law of treaties and on international responsibility. Part 1 introduces the debate with an example concerning the nature of UN Security Council anti-terrorism resolutions. Part 2 challenges the four theories of the rules envisaged by scholarship. Part 3 is an attempt to examine the characteristics of the legal system produced by international organizations taking advantage of analytical jurisprudence, developing a theory of their legal nature defined as 'dual legality'. Part 4 concludes by appraising the effects of the dual legality looking at the law of treaties, international responsibility and invalidity for ultra vires acts.
\end{abstract}

\section{Keywords}

Rules of international organizations - responsibility - law of treaties - legal theory - legal pluralism - invalidity for ultra vires acts - member states

* PhD, University of Milan; MIL/LLM, Graduate Institute of International and Development Studies. Visiting Fellow at the Max Planck Institute for Comparative Public Law and International Law and postdoctoral researcher at the Erik Castrén Institute of International Law and Human Rights (University of Helsinki. The author would like to thank the anonymous reviewers of the IOLR for very valuable comments, as well as the entire community of the law department of the Graduate Institute and of the Erik Castrén Institute. 
At first sight, the legal nature of the rules of international organizations is a forgotten issue, characterized by legal formalism dating back to the beginning of the $20^{\text {th }}$ century. ${ }^{1}$ In order to introduce the theme and brush away some dust, it is convenient to look at the nature of the resolutions the United Nations Security Council ('UNSC') has adopted in its anti-terrorism agenda. ${ }^{2}$ Are they international law or internal law of the United Nations ('UN')? The question, at first glance, may "now appear quaint or irrelevant", ${ }^{3}$ without particular consequences. Yet, how can we, for example, build a system of accountability if we do not even know which legal system of reference we must consider to ascertain an alleged ultra vires character? ${ }^{4}$

On the one hand, if the system of norms arising from the Charter of the United Nations is the answer, the resolution may be merely internal law, leading to a rigid separation between legal systems. As such, the internal nature may prompt a counter effect of the Kadi judgment of the European Court of Justice. ${ }^{5}$ Indeed, the UN could argue that invalidity of one of its internal rules is possible under its own legal system only, and that such invalidity does not trigger international responsibility. Not unlike the European Court of Justice, the UN may affirm that an alleged human rights violation may only be contested within the framework of its own rules and its own parameters. The resolution may be deprived of its effects in a different legal system, with a different human rights standard, but this need not limit its validity. Otherwise, only international organizations with a high level of integration could claim that internal rules exist separately from international law. ${ }^{6}$

\footnotetext{
${ }^{1}$ The majority of scholars wrote on the topic until the 70s. For a recent overview of the historical discourse on the nature of the rules, see C.Ahlborn, 'The Rules of International Organizations and the Law of International Responsibility' (2011) 8(2) International Organizations Law Review 397.

${ }^{2}$ A Bianchi and A Keller (eds), Counterterrorism: Democracy's Challenge (Hart Publishing, 2008); A Bianchi (ed), Enforcing International Law Norms Against Terrorism (Hart Publishing, Oxford, 2004); B Saul (ed), Research Handbook on International Law and Terrorism (Edward Elgar Publishing, 2014).

${ }^{3}$ J E Alvarez, International Organizations as Law-makers (Oxford University Press, 2006) 119.

${ }^{4} \mathrm{~S}$ Zappalà, 'Reviewing Security Council Measures in the Light of International Human Rights Principles', in B Fassbender (ed), Securing Human Rights? Achievements and Challenges of the UN Security Council (Oxford University Press, 2011).

${ }^{5}$ Yassin Abdullah Kadi and Al Barakaat International Foundation $v$ Council of the European Union and Commission of the European Communities (European Court of Justice, Joined Cases C-402-05 P and C-415/05 P, 3 September 2008).

${ }^{6}$ As we will see, the thesis is mainly supported by the advocates of a European exception. See, eg, F Hoffmeister, 'Litigating against the European Union and Its Member States - Who Responds under the ILC's Draft Articles on International Responsibility of International Organizations?'(2010) 21(3) The European Journal of International Law 724; M P J Kuijper and E Paasivirta, 'EU International Responsibility and its Attribution: From the Inside Looking Out', in M Evans and P Koutrakos (eds), The International Responsibility of the European Union (Hart Publishing, 2013); J M Cortés Martìn, 'European Exceptionalism in International Law? The European Union and the System of International Responsibility', in M Ragazzi (ed), Responsibility of International Organizations (Martinus Nijhoff, 2013).
} 
On the other hand, if resolutions are found to constitute international law, the very existence of the UN legal system is in trouble. Indeed, that would mean that the international source of its rules, the Charter of the United Nations, does not allow for the development of a legal system. Further, the nature of its secondary norms (secondary in the sense that they derive from a primary source, the Charter of the United Nations) would essentially derive from the international conduct of member states. Would this conflict with the conclusions of the International Court of Justice ('ICJ') on the "organized legal system of the United Nations"? The question could still perhaps be answered in the negative. Indeed, the ICJ was only referring to the Administrative Tribunal in the context of employment relations. Then again, maybe the UN has a legal system that includes only administrative rules, leaving outside everything with an international character. ${ }^{8}$

This example introduced only one consequence of the different legal natures of a peculiar instrument falling in the broad category labelled 'rules of international organizations'. Conversely, this paper argues that every rule of every international organization must share the same nature, rebutting theories based on exceptions founded over the characteristics of only certain organizations or the differences between different categories of rules. The dual legality is an attempt to unify the nature of the rules recognizing the dual image of international organizations. On the one side they constitute autonomous legal systems, on the other they are functionalist entities. ${ }^{9}$ As Virally asked in 1972:

Qu'y a-t-il de vrai dans cette double vision, superposant deux images apparemment antinomiques: le positif et le négatif sur la même feuille? Est-il correct de dire: l'O.N.U. n'a pas réussi à prévenir la guerre des six jours au Proche Orient? N'est- ce pas céder à la tentation du nominalisme? Ne serre-t-on pas la réalité politique de plus près en disant: les Etats qui exercent une influence au Proche-Orient, à commencer par les super-grands, $n$ 'ont pas été capables de

${ }^{7}$ Effect of Awards of Compensation made by the United Nations Administrative Tribunal [1954] ICJ Rep 47, 55-56.

${ }^{8}$ As we will see, the thesis is mainly supported by inquiries on employment relations within international organizations (see C F Amerasinghe, The Law of the International Civil Service (Clarendon Press, 1994)) and by inquiries on global administrative law (see B Kingsbury, 'The Concept of Law in Global Administrative Law' (2009) 20(1) European Journal of International Law 29).

9 J Klabbers, 'The EJIL Foreword: The Transformation of International Organizations Law' (2015) 26(1) European Journal of International Law 9. 
prévenir la guerre au Proche-Orient, en utilisant les moyens d'action offerts par

la Charte et la machinerie des Nations Unies? ${ }^{10}$

These questions still remain unanswered.

Since the United Nations Conference on the Representation of States in their Relations with International Organizations of 1975, the rules of international organizations have been defined as including "the constituent instruments, relevant decisions and resolutions, and established practice of the Organization". ${ }^{11}$ This definition, reproduced with minor changes in the 1986 Vienna Convention on the Law of Treaties between States and International Organizations or between International Organizations ('1986 Vienna Convention') and in the 2011 Articles on the Responsibility of International Organizations ('ARIO'), reflects the need for a broad notion of the rules - discussed, but not included, in the 1971 Draft Articles by the $\mathrm{ILC}^{12}$ - and the discussion on the nature of international organizations in the context of the law of treaties. ${ }^{13}$ While its works have served as a basis for the development of a definition of the rules, the International Law Commission ('ILC') has so far refrained from assuming a clear stance on their legal nature. ${ }^{14}$ As the commentary to the Draft Article 3 adopted in the 2002 ILC session explicitly states, "the internal law of an international organization cannot be sharply differentiated from international law. At least the constituent instrument of the international organization is a treaty or another instrument governed by international law; some further parts of the internal law of the organization may be viewed as belonging to international law ... Thus, the relations between international law and the internal law of an international organization appear too complex to be expressed in a general principle". ${ }^{15}$ This complexity is

10 M Virally, L'organisation mondiale (Armand Colin, 1972) 30. (What is true in this double image, superimposing two seemingly antinomic images: the positive and the negative on the same sheet? Is it correct to say: the UN failed to prevent the six-day war in the Middle East? Is not this to yield to the temptation of nominalism? Are we not closer to the political reality saying that the states that exert an influence in the Middle East, starting with the superpowers, have not been able to prevent the war in the Middle East, using the means of action offered by the United Nations Charter?)

${ }^{11}$ M H Randal, 'Vienna Convention on the Representation of States in their Relations with International Organizations of a Universal Character (1975)' in R Wolfrum (ed), Max Planck Encyclopedia of Public International Law (Oxford University Press, 2007).

12 'Relations between States and International Organizations' [1971] II(1) Yearbook of the International Law Commission 288.

13 See especially the $14^{\text {th }}, 15^{\text {th }}, 16^{\text {th }}$, and $17^{\text {th }}$ ILC meetings.

14 'Draft articles on the responsibility of international organizations, with commentaries' [2011] II(2) Yearbook of the International Law Commission, Commentary to Article 10.

15 'Report of the International Law Commission on the work of its fifty-fifth session (5 May-6 June and 7 July-8 August 2003) [2003] II(2) Yearbook of the International Law Commission 23. 
the common root of a number of fundamental dichotomies that affect the nature of international organizations: the theory of attribution of competences or the theory of implied powers; ${ }^{16}$ legal personality coming from the will of member states or from general international law; ${ }^{17}$ the institutional instrument seen as a treaty or as a constitution; ${ }^{18}$ "open structures that are vehicle for states" or "closed structures that are independent legal actors"; 19 and functionalism or constitutionalism. ${ }^{20}$ Indeed, the unclear nature of the rules is the main cause of the unclear relationship between the organization and its member states, which remains the unresolved problem of the institutional architecture of international organizations. ${ }^{21}$ To introduce a leitmotiv that will be developed further, when a rule is perceived as purely international, member states are considered as third parties; when the same rule is perceived as purely internal, member states are considered as organs. The development of a theoretical discourse on the dual legality of the rules of international organizations is an attempt to fully recognize the flaws of functionalism and the unrealism of constitutionalism. The dual nature is a direct consequence of the peculiar legal system created by international organizations and the cause of their transparent institutional veil. ${ }^{22}$

Four Different Theories on the Nature of the Rules

In the framework of the broad definition of the rules, inclusive of every instrument that derive from the legal system of the organization, the International Law Commission identifies four different theories on their legal nature. ${ }^{23}$ Two can be traced back to the first wave of the studies on international organizations: ${ }^{24}$ the first relies on the distinction between a group of internal

\footnotetext{
${ }^{16}$ H G Schermers and N M Blokker, International Institutional Law: Unity within Diversity (Martinus Nijhoff, $5^{\text {th }}$ ed, 2011) [206]-[236].

${ }^{17}$ F Seyersted, Objective International Personality of Intergovernmental Organisations: Do Their Capacities Really Depend upon Their Constitutions? (Copenhagen, 1963); K Zemanek, 'International Organizations: Treaty-Making Power' in Encyclopedia of Public International Law (1983) 168-171.

18 S Rosenne, Developments in the Law of Treaties, 1945-1986 (Cambridge University Press, 1989) 181; T Sato, Evolving Constitutions of International Organizations (Kluwer Law International, 1996).

${ }^{19}$ C Brölmann, The Institutional veil in Public International Law (Hart Publishing, 2007) 1.

$20 \mathrm{~J}$ Klabbers, 'Contending Approaches to International Organizations: Between Functionalism and Constitutionalism' in J Klabbers and $\AA$ Wallendahl (eds), Research Handbook on the Law of International Organizations (Edward Elgar, 2011) 3.

21 J Klabbers, An Introduction to International Institutional Law (Cambridge University Press, 2009) 31, 308.

22 Brölmann, above n 19.

23 'Draft articles on the responsibility of international organizations, with commentaries' [2011] II(2) Yearbook of the International Law Commission, Commentary to Article 10, [5].

${ }^{24}$ J Klabbers, 'The Life and Times of the Law of International Organizations' (2011) 70(3) Nordic Journal of International Law 287.
} 
administrative rules and a group of external international rules; ${ }^{25}$ the second relies on the differences between international organizations, limiting the capacity to produce internal norms only to those having a higher degree of integration, based primarily on the specificity of the European Union ('EU'). ${ }^{26}$ These may be labelled 'hybrid' theories, insofar as they do not provide a comprehensive understanding that applies uniformly to each of the rules. The other two, developed on the basis of the distinction between original and derivative legal systems, ${ }^{27}$ rely on a clear-cut dichotomy: either the rules are part of international $\operatorname{law}^{28}$ or they merely constitute internal law. ${ }^{29}$

\subsection{Hybrid Theories}

Most scholars look at the rules with only a limited group of norms concerning the administrative function of the organization, or only the characteristics of certain organizations in mind. ${ }^{30}$

Under the first theory, the distinction is usually drawn between internal and external rules. ${ }^{31}$ However, there is not a clear-cut differentiation and every author almost arbitrarily decides where the internal rules stop and the external start. The distinction between internal and international law arising from the legal system of an international organization varies from the minimum internal core of employment relations ${ }^{32}$ to the maximum internal core of Global Administrative Law. ${ }^{33}$

It is useful to discuss the issue looking at an instrument of Global Administrative Law having the form of a rule of international organizations: for example, International Health

25 P Kazanski, 'Théorie de l'administration internationale' (1902) 9 Revue Général de Droit Internaitonal Public 353; U Borsi, 'Il rapporto di impiego nella società delle nazioni' (1923) XV Rivista di diritto internazionale 283; S Basdevant, Les fonctionnaires internationaux (Parigi, 1931); P Negulesco, 'Principes de droit international administrative' (1935) I Recueil des Cours de l'Académie de Droit International de l'Haye 643; A Rapisardi-Mirabelli, Il diritto amministrativo internazionale (Padova, 1939); C W Jenks, The Proper Law of International Organizations (Oceana, 1962).

${ }^{26} \mathrm{G}$ Gaja, Third report on responsibility of international organizations, UN Doc A/CN.4/553 (13 May 2005), and the debate in the $2840^{\text {th }}$ and $2843^{\text {th }}$ ILC meetings.

27 P Cahier, 'Le droit interne des organisations internationales' (1963) 67 Revue Générale de Droit International Public 563.

${ }^{28} \mathrm{M}$ Decleva, Il diritto interno nelle unioni internazionali (Padova, 1962).

29 A P Sereni, Le organizzazioni internazionali (Milano, 1959).

${ }^{30}$ R Monaco, Lezioni di organizzazione internazionale (Giappichelli, 1985) 199.

31 Schermers and Blokker, above n 16.

32 Amerasinghe, above n 8.

33 B Kingsbury, N Krisch, and R B Stewart, 'The Emergence of International Administrative Law' (2005) 68(3) Law and Contemporary Problems 57. 
Regulations. ${ }^{34}$ They are a peculiar source of law arising from Articles 21 and 22 of the World Health Organization's ('WHO') Constitution with a rare binding force in order to face health crises. ${ }^{35}$ The WHO Assembly adopts them with simple majority and they come into force for all member states after due notice and with the possibility of opting out within a short period. ${ }^{36}$ The question here is where the administrative function ends. Health regulations can be framed as external or internal instruments simply depending on the perspective. This ambiguity has relevant consequences, as the internal nature of the regulations may be submitted to the dispute settlement mechanism envisaged in Article 56 of the International Health Regulations, while their external nature may be submitted to the general rules of the responsibility of international organizations. The legal counsel of the World Health Organization affirmed that the rules might allow the development of a "customized internal legal order that could avoid legal controversies about rather minor issues". 37 The World Health Organization stated that the obligations arising directly from its constituent instrument are necessarily international obligations, save for staff regulations. ${ }^{38}$ What is, then, the administrative function of an international organization? Following the first hybrid theory, the lawmaking process of international organizations can create something that is internal or administrative and something that is international. The distinction between internal and external rules drawn by some authors is useful insofar as it describes the qualities of the law produced by international organizations, ${ }^{39}$ but it is not a normative description based on the legal nature of the rules. The theory that discusses the hybrid nature of the rules differentiating between internal sources is therefore not acceptable, since whatever comes from a rule of recognition must belong to the system of its origin. ${ }^{40}$ If the World Health Organization develops a legal system, the entire body of law produced by the organization must respond to the same rule of recognition, be it internal, international, or dual. And, as a number of scholars readily acknowledge, inside an

\footnotetext{
34 J Benton Heath, 'SARS, the 'Swine Flu' Crisis and Emergency Procedures in the WHO' in S Cassese et al (eds), Global Administrative Law, The Casebook (2012).

35 D P Fidler, 'From International Sanitary Conventions to Global Health Security: The New International Health Regulations' (2005) 4 Chinese Journal of International Law 325.

36 B Plotkin, 'Human rights and other provisions in the revised International Health Regulations (2005)' (2007) 121(11) Public Health 840.

37 G L Burci and C Feinäugle, 'The ILC's Articles Seen from a WHO Perspective' in M Ragazzi (ed), Responsibility of International Organizations (Martinus Nijhoff, 2013) 186.

38 Responsibility of International Organizations: Comments and observations received from international organizations, UN Doc A/CN.4/568 (17 March 2006) 4.

39 See, eg, Schermers and Blokker, above n 16.

${ }^{40}$ H L A Hart, The Concept of Law (Clarendon Press, 1961).
} 
international organization there cannot be something internal and something external. ${ }^{41}$ Every rule must share the same nature.

Under the second theory, the distinction is made looking at the organization that may possess an internal legal system. ${ }^{42}$ The discussion distinguishes organizations such as the European Union (a minimum value) from those of the kind of the Conferences of the Parties or other semi-autonomous bodies of international law (a maximum value). It is mainly an issue of definition of international organizations and their capacity to develop a legal system.

During the ILC debate on the provisional Article 8 of the $A R I O$-entitled "existence of a breach of an international obligation" 43 _ Special Rapporteur Giorgio Gaja affirmed that "he personally would prefer wording that excluded the rules of regional organizations that had given rise to a form of integration entailing a system of law that could no longer be regarded as part of international law". ${ }^{44}$ Why, one may ask, circumscribe the existence of internal rules only in the context of regional organizations? Why would the rules of the European Union have a different legal nature than those of the United Nations? After all, in the context of international responsibility, the specificities of the United Nations are better represented than those of the European Union through Article 67 of the ARIO (in parallel with Article 59 of the Articles on the Responsibility of States for Internationally Wrongful Acts). ${ }^{45}$

The topic is framed within the fragmentation of international law and self-contained regimes regulated by lex specialis. ${ }^{46}$ Looking at the European Union, the absence of an ad hoc provision in the ILC project was mitigated by the role of the article on lex specialis, which allows the application of internal EU rules derogating from the draft articles. ${ }^{47}$ The lex specialis provision is applicable to any organization, underlining the international nature of the rules, while the introduction of an ad hoc article would have implicitly underlined the internal nature of EU law. ${ }^{48}$ There is not a European exception; there is a relation lex specialis/lex generalis

\footnotetext{
${ }^{41}$ Monaco, above n 30; Alvarez, above n 3.

42 Monaco, above n 30.

${ }^{43}$ See especially the $2840^{\text {th }}$ and $2843^{\text {th }}$ ILC meetings.

44 See 'Summary record of the $2843^{\text {rd }}$ meeting' [2005] I Yearbook of the International Law Commission 96.

${ }^{45}$ V Gowlland-Debbas, 'Responsibility and the United Nations Charter' in J Crawford, A Pellet, and S Olleson (eds), The Law of International Responsibility (Oxford University Press, 2010).

46 B Simma and D Pulkowski, 'Of Planets and the Universe: Self-contained Regimes in International Law' (2006) 17(3) European Journal of International Law 483.

${ }^{47}$ Kuijper and Paasivirta, above n 6.

${ }^{48}$ Hoffmeister, above n 6.
} 
between regimes foreseeing a possible coordination. ${ }^{49}$ Any distinction between international organizations has merely a descriptive character and it cannot justify the difference between an organization with international rules and one with internal rules. What matters is that once a legal system is established, it produces law despite its varied characteristics. Either every international organization creates internal law, every international organization creates international law, or every international organization creates dual law. There can be no exceptions.

In summary, the hybrid-nature theory can be contested affirming that: 1) when a legal system is created it cannot produce two different kinds of law belonging to two different legal systems; and 2) when a legal system is created, it produces law, despite the characteristics of the system itself.

\subsection{Comprehensive Theories}

Not many legal scholars look at an international organization as a unique body of law. The doctrine lacks a study on this particular topic, and there is generally little understanding of the inclusiveness of the category of the rules. There is, however, a distinction between the ideas of international organizations built over a constitution or over a contract. ${ }^{50}$ The constitutional view relies on the public dimension of international institutions, while the contractual view is based on the analogy with private national enterprises. ${ }^{51}$ The first perspective looks at the rules as internal law, the second as international law.

In the development of a theory based on the internal nature of the rules it is possible to recognize a slow descent toward its extreme consequences. Initially, the nature of the rules was devoid of much scholarly attention, and so was their definition; commentators focused more on autonomy and legal personality. ${ }^{52}$ After the adoption of the clear all-encompassing category included in the Vienna Convention on the Representation of States in their Relations with

49 G Marhic, 'Le régime de responsabilité des opérations de paix de l'Union européenne: quelles règles applicables?' (2013) 1 Revue Belge de Droit International 137.

50 J Klabbers, 'Two Concepts of International Organizations' (2005) 2(2) International Organizations Law Review 277.

51 J D'Aspremont, 'The Law of International Organizations and the Art of Reconciliation: From Dichotomies to Dialectics’ (2014) 11(2) International Organizations Law Review 428.

52 L Focsaneanu, 'Le droit interne de l'organisation des Nation Unies' (1957) 3 Annuaire Français de Droit International 315; A P Sereni, Organizzazione internazionale. Soggetti a carattere funzionale: le organizzazioni internazionali (A Giuffrè, 1960) vol 2, s 2; P Cahier, above n 27; J A Barberis, 'Nouvelles questions concernant la personnalité juridique internationale' (1983) 179 Recueil des cours de l'Académie de Droit International de l'Haye 145. 
International Organizations of a Universal Character of $1975,{ }^{53}$ scholars started to draw a distinction between internal and external functions, relying on the internal nature of the external functions. ${ }^{54}$ At that point the path diverges, towards an hybrid nature on the one side or a coherent internal nature on the other. ${ }^{55}$ In 2011, Christiane Ahlborn brought the internal nature of the rules to their extreme and necessary consequences, contesting their lex specialis relation with international law. ${ }^{56}$ Since the rules belong to a different legal system, they are not lex specialis in relation to international law and therefore Article 64 of the ARIO should be expunged. It is through the relationship between internal lex specialis and international lex generalis that the limits of the exclusively internal nature of the rules becomes evident, since it is unable to acknowledge their inherent belonging to international law. ${ }^{57}$

The exclusively internal character of the rules of international organizations is unable to recognize the international self-contained nature of the legal systems of international organizations. ${ }^{58}$ This deficiency has been perfectly described in the context of the World Trade Organization ('WTO') by Joost Pauwelyn. ${ }^{59}$ His monograph is devoted to demonstrating that WTO law is part of international law. He describes the relationship between the internal and the international dimensions of the organization using the tools provided by the law of treaties and stressing the existence of two inherent tensions between the fall-back to and the contract out of international law. The degree of permeability between the two systems does not allow an absolute internal nature of the rules.

Concerning the last theory, the international nature of the rules has its limits too. As we have seen, Pauwelyn demonstrates that WTO law is not isolated from international law. ${ }^{60}$ Yet,

\footnotetext{
${ }^{53}$ See the introduction.

${ }^{54} \mathrm{P}$ Cahier, 'L'ordre juridique interne des organisations internationales' in R J Dupuy (ed), Manuel sur les organisations internationales (Martinus Nijhoff, 1998); Schermers and Blokker, above n 16; H G Schermers, 'The Legal Basis of International Organization Action', in R J Dupuy (ed), Manuel sur les organisations internationales, (Martinus Nijhoff, 1998).

${ }^{55} \mathrm{P}$ Klein, La responsabilité des organisations internationales dans les ordres juridiques internes et en droit des gens (Bruylant, 1998); P Klein and P Sands, Bowett's law of international institutions (Sweet \& Maxwell/Thomson Reuters, 2009); F Seyersted, Common Law of Intergovernmental Organizations (Martinus Nijhoff, 2008).

${ }^{56}$ Ahlborn, above $\mathrm{n} 1$.

57 M Forteau, 'Régime général de responsabilité ou lex specialis?'(2013) 46(1) Revue belge de droit international 147.

${ }^{58}$ See the debate of the study group on the responsibility of international organization during the $75^{\text {th }}$ Conference of the International Law Association, 'Responsibility of International Organizations' (2012) 75 International Law Association Reports of Conferences 880.

59 J Pauwelyn, Conflict of Norms in Public International Law: How WTO Law Relates to Other Rules of International Law (Cambridge University Press, 2003).

${ }^{60}$ Ibid.
} 
the WTO itself contests the international nature of the rules when it looks at EU law. ${ }^{61}$ WTO panels consider EU member states as organs of the organization. ${ }^{62}$ If the WTO seeks to ensure compliance to its rules it must consider the EU as the sole responsible entity. ${ }^{63}$ The fact that the WTO looks at an international organization as a unique international entity (where member states are mere organs) implies an internal nature of European Union law that regulates the internal relations between and with member states. ${ }^{64}$ The international nature is linked with a corporation-like vision of international organizations. ${ }^{65}$ When Pauwelyn discusses the reciprocal nature of WTO obligations against what he called an 'integral' character, he is underlining the contractual and therefore international basis of WTO law. ${ }^{66}$ This is a form of legitimization of the organization that takes advantage of the derivation from international law in order to play down the particularities of the legal system.

The international nature is strictly related to functionalism. Jan Klabbers defines functionalism as "essentially a principal-agent theory, with a collective principal (the member states) assigning one or more specific tasks - functions - to their agent". ${ }^{67}$ Functionalism affects the nature of the rules imposing a rigid international nature, under which the agent exercises his functions in the framework of the same legal system in which the 'master' delegated his power. ${ }^{68}$ As Klabbers contests, this is not compatible with empirical phenomena that underline the wide autonomy of international organizations. Functionalism cannot explain the development of an independent legal system and consequently the internal nature of its rules. The traditional support for functionalist theories brought a number of scholars to imply the international nature, even if most of the times this stance is not clearly acknowledged. ${ }^{69}$

61 See, eg, Panel Report, Protection of Trademarks and Geographical Indications for Agricultural Products and Foodstuffs (United States v European Communities), WTO Doc WT/DS174/R (20 April 2005) [7.725] ('EC-Trademarks case'). The same view was taken by a panel in Panel Report, Measures Affecting the Approval and Marketing of Biotech Products (United States v European Communities), WTO Docs WT/DS291/R; WT/DS292/R; and WT/DS293/R (29 September 2006) [7.101].

62 Panel Report, EC - Selected Customs Matters, WTO Doc WT/DS315/R (12 June 2006). See especially [7553].

${ }^{63}$ P J Kuijper, 'Attribution - Responsibility - Remedy. Some comments on the EU in different international regimes' (2013) 46(1) Revue belge de droit international 115.

${ }^{64}$ Ahlborn, above $\mathrm{n} 1$.

${ }^{65} \mathrm{C}$ F Amerasinghe, Principles of the Institutional Law of International Organisations (Cambridge University Press, 2005) 13.

66 Pauwelyn, above n 59, 57.

${ }^{67}$ Klabbers, above n 9, 10.

${ }^{68}$ D Saarooshi, 'International organizations: personality, immunity and responsibility', in D Saarooshi (ed), Remedies and Responsibility for the Actions of International Organizations (Martinus Nijhoff, 2014).

69 D Anzilotti, Cours de droit international (Recueil Sirey, 1929) 295-296; P C Jessup, 'Parliamentary Diplomacy - An Examination of the Legal Quality of the Rules of Procedure of Organs of the United Nations' (1956) 89 Recueil des Cours de l'Académie de Droit International de l'Haye 204; Jenks, above n 25; P Daillier 
However, as early as 1969, Balladore Pallieri found that an internal system of rules cannot exist without its own legal system. ${ }^{70}$ In his view, if an organization is unable to produce a legal system, its rules are not law at all. This conclusion is inherent in the existence of a legal system different from international law and derives from basic assumptions of analytical jurisprudence.

The fallacy of considering the rules as a body of law belonging to internal or international law is a consequence of the 'transparent institutional veil', defined as "an endemic condition of intergovernmental organisations in general international law, partly due to the other two features counteracting: it indicates that organisations are neither entirely closed-off to international law in the way of states, nor entirely open, as instances of non-institutionalised inter-state cooperation would be". ${ }^{71}$ The idea of organizations as semi-open and semi-closed reflects the dual legality of its rules. ${ }^{72}$

\section{A Venture into Legal Theory}

This section deviates from the usual framework of the discourse on international organizations. It will merge issues arising from the existence of transnational regimes with the traditional debate on well-established subjects of international law. ${ }^{73}$

The common denominator is analytical jurisprudence, seen as an attempt to provide an answer to the questions of what law and a legal system are, and how such a system must be organized in its internal and external dimensions. ${ }^{74}$ The intention here is to make "an effort to understand the nature of a social institution and its products". ${ }^{75}$

Therefore, the legal nature of the rules will be framed according to two lines: first, the formal interaction between legal systems: "what makes it separate from another?";76 and

and A Pellet, Droit international public (Librairie générale de Droit et de Jurisprudence, $7^{\text {th }}$ ed, 2009); M N Shaw, International Law (Cambridge University Press, $7^{\text {th }}$ ed, 2014) 948; E Lagrange and J Sorel, Droit des organisations internationals (Lextenso, 2013); Amerasinghe, above n 65.

${ }^{70}$ G Balladore Pallieri, 'Le droit interne des organisations internationales' (1967) 127 Recueil des cours de l'Académie de Droit International de l'Haye 1.

${ }^{71}$ Brölmann above n 19, 11.

72 Ibid 253.

${ }^{73}$ The journey will be mainly guided by T Schultz, Transnational Legality: Stateless Law and International Arbitration (Oxford University Press, 2014).

$74 \mathrm{~J}$ Raz, The Concept of a Legal System (Claredon Press, 2003).

75 S J Shapiro, Legality (Belknap Press, 2011) 7.

${ }^{76}$ M van de Kerchove and F Ost, Legal System between Order and Disorder (Oxford University Press, 1994) 135 . 
second, the importance of the point of view: asking "is it law?" is a different question from asking "is it law of which legal system?"77

\subsection{Original and Derivative Legal Systems}

The interaction between legal systems developed by international organizations is mainly expressed in the original/derivative dialectic. On the one hand, there is the idea of organizations as original social entities, under which the efficacy of their internal norms is not subjected to international law. ${ }^{78}$ On the other hand, there is derivation, where the nature of the legal system comes from the will of member states seen as primary subjects of international law. ${ }^{79}$

This original/derivative dichotomy has its origin in the work of Santi Romano. ${ }^{80}$ Santi Romano's concept of an 'institution' equated to a legal system is linked to the idea of interconnection, where different orders are independent for some aspects and part of the same system for others. ${ }^{81}$ The institution created by states is just one between others, which can be internal, external, overlapping, presupposed, or derived. ${ }^{82} \mathrm{He}$ explains their relationships with the concept of relevance/irrelevance, which is a legal relationship based on the different ways in which legal systems interconnect. ${ }^{83}$

The existence of original and derivative legal systems is related to what Santi Romano calls 'presupposition', which is the existence of a legal system founded over a preexisting legal system. ${ }^{84}$ For Santi Romano, this is the relationship between states and international law, since states presuppose the international society. This example shows that Santi Romano's 'presupposition' is based on the importance of the founders of a legal system. The supporters of the derived nature of international organizations follow the idea. ${ }^{85}$ However, looking at individuals can challenge this thesis. They should be the only presupposition of any legal system. This is a problem of subjects, and does not concern the source of its creation. Moving from his theory, it is affirmed here that presupposition is not based on the preexistence of the founder subjects, but on the formalistic creation of an order over sources of law of the

${ }^{77}$ Schultz, above n 73, 10-11.

${ }^{78}$ Sereni, above $\mathrm{n} 29$.

${ }^{79}$ Decleva, above $\mathrm{n} 28$.

${ }^{80} \mathrm{~S}$ Romano, L'ordinamento giuridico (Pisa, 1917).

${ }^{81}$ Ibid 95.

${ }^{82}$ F Fontanelli, 'Santi Romano and L'ordinamento giuridico' (2011) 2(1) Transnational Legal Theory 67.

${ }^{83}$ Schultz, above $\mathrm{n} 73,86$.

${ }^{84}$ Romano, above n 80, 130.

${ }^{85}$ Decleva, above $\mathrm{n} 28$. 
preexistent order. Its subjects may vary, but the international legal system is not founded over a source of national law. Similarly, state systems are not founded over sources of international law. Both are original legal systems without a relationship of derivation.

The legal system of international organizations is founded over a source of international law; member states are at the same time subjects of international law and of the organization. The two orders are not in a relationship of equality or independence, since one is the presupposition of the other.

When a derivative legal system is created, how is it affected by the preexisting system? How does international law influence international organizations? Can an organization abandon its derivative character founding an original legal system with an internal act of will? Can the validity of a rule of the organization be subjected to international law? Can international law impose its external effects on international organizations? What are the external effects between organizations?

The second theme to discuss is the relevance of the point of view.

\subsection{Relative and Absolute Legality of the Rules}

Relevance can adopt different points of view: "order A may be relevant for B but not for C, while both B and C may be irrelevant for A". ${ }^{86}$ The first distinction to be made is between the importance of the assertion that the legality of a system depends on its recognition by others legal systems and the so-called "absolute legality" of the legal system recognized by an external observer. $^{87}$

The relative legality of a norm is what a legal system perceives through its own rules of recognition. It could consist in the recognition of a norm as its own law, or it could consist in the recognition of a norm as part of a different legal system. It is still an internal point of view. ${ }^{88}$ When a legal system applies a norm recognizing its belonging to another legal system it reproduces the content of the norm inside its own system despite the internal point of view of the system that created that norm, and despite the absolute legality of that legal system.

An external observer attributes the absolute legality of a norm. The observer must be external to any legal system in order to maintain an analytical and descriptive position. He does not accept the rule of recognition of the system under study. ${ }^{89}$ This prompts us to consider two

\footnotetext{
86 Schultz, above n $73,86$.

${ }^{87}$ Ibid 81.

${ }^{88}$ Hart, above n 40, 100.

89 Ibid 102.
} 
different points of view from which legal phenomena may be apprehended. ${ }^{90}$ The internal perspective means to adhere to the discourse that institutions use about themselves, while the external perspective supposes an epistemological break. ${ }^{91}$

As to the rules of international organizations, distinguishing between different perspectives of legality is fundamental: indeed, it is a consequence of the fact that the point of view could change the nature of the rule. If the actors of the international legal system, through its lawmaking mechanism, say that Security Council resolutions are international law, they become law of this system under its perspective. If the actors of the organization legal system, through its lawmaking mechanism, say that Security Council resolutions are internal law, they became law of that system. In both cases, this happens despite the absolute nature of the rules. They still became law of the system of reference. It is a consequence of the so-called Midas principle: ${ }^{92}$ on the one hand, what a legal system says is law becomes law belonging to that legal system; on the other hand, what legal system A says is law that belongs to legal system $\mathrm{B}$ becomes law of that system under the perspective of A. "The power to determine relative legality belongs to the official of the recognizing system". ${ }^{93}$

Distinguishing between points of view is an epistemological orientation. ${ }^{94}$ Moving from Hart, Kerchove and Ost consider the existence of an internal and external point of view. Both can be modified, introducing the category of 'internalité', which admits the possibility that the point of view adopts a different point of view. ${ }^{95}$ Therefore, there is a radical external point of view when the external point of view does not take into account the internal point of view; there is a moderate external point of view when the external point of view takes into account the internal point of view without adopting it. ${ }^{96}$

On the one hand, a radical internal point of view is adopted when a subject of the international legal system looks at the rules of international organizations as international law. Even considering the existence of a different legal system, the subject of international law defines the rule of the organization as its own law, despite the internal point of view of the

\footnotetext{
90 Ibid.

91 van de Kerchove and Ost, above n 76, 6-7.

92 H Kelsen, Pure Theory of Law (University of California Press, 1967) 161.

93 Schultz, above n 73, 84.

94 van de Kerchove and Ost, above n 76.

$95 \mathrm{M}$ van de Kerchove and F Ost, Jalons pour une théorie critique du droit (Publications des Facultés universitaires Saint-Louis, 1987) 28.

96 van de Kerchove and Ost, above n 76, 9.
} 
organization. This is what happens when a state (wearing the clothes of a subject of the international legal system) considers a resolution of the Security Council.

On the other hand, the same radical internal point of view is adopted when a subject of the organization's legal system considers a rule merely internal law. This is what happens when a state (wearing the clothes of a subject of the organization's legal system) considers a regulation of the European Union.

It is affirmed here that absolute legality, defined as "something descriptively attributed to a normative system by an observer" 97 must be an external point of view adopted taking into consideration the internal point of view, without adopting it and applying what for Ost and Kerchove would be a moderate external point of view.

In order to define absolute legality, it is necessary to look at the interaction between legal systems. Absolute legality is an attempt to recognize the plurality of points of view, and it can succeed in looking at the formal interaction between legal systems, which, in case of international organizations, is a relationship based on presupposition from international law.

\subsection{The Dual Legality of the Rules}

The absolute legality of the rules of international organizations is a combination of the derivative character of the legal system that produces them (the external 'absolute' point of view) and the legal system that looks at the rules (the internal 'absolute' point of view that depends on the system of reference).

The conclusion is that the rules of international organizations serve as law for two different legal systems. They have, in other words, a dual nature. This is something different from recognizing the effects of the Midas principle, where each legal system has the power to reproduce the content of an external rule. In fact, Midas creates two rules, with more or less the same content (but not necessarily, as a system may misrepresent a rule of another system). Dual legality, instead, shares the same rule; it is only the point of view that changes. The theory is a sort of dédoublement fonctionnel of the rules of the organization. ${ }^{98}$ Scelle's pluralism is compatible with Santi Romano's theory, adding the hierarchical character of the relations between systems. ${ }^{99}$ Under his theory, individuals, agents of one legal system, can use their

${ }^{97}$ Schultz, above n $73,87$.

${ }^{98} \mathrm{G}$ Scelle, 'Le phénomène juridique du dédoublement fonctionnel' (1956) Rechtsfragen der Internationalen Organisation - Festschrift für H. Wehberg 324.

99 A Cassese, 'Remarks on Scelle's Theory of 'Role Splitting' in International Law' (1990) 1 European Journal of International Law 210. 
functional capacity to guarantee the efficacy of norms belonging to a different legal system. This capacity is connected to the hierarchy between legal systems. ${ }^{100}$ A similar relation built the rules of international organizations.

Actually, the dual legality of constitutive instruments has been recognized since the first studies on international organizations, ${ }^{101}$ with a further development in the distinction between the contractual and the legislative nature of treaties. ${ }^{102}$ Contemporary scholars have debated the issue, ${ }^{103}$ and the International Court of Justice has repeatedly recognized it. In Certain Expenses, it stressed the special character of the Charter of the United Nations, ${ }^{104}$ while in Nuclear Weapons in Armed Conflict it expressly affirmed that "the constituent instruments of international organizations are also treaties of a particular type; their object is to create new subjects of law endowed with a certain autonomy, to which the parties entrust the task of realizing common goals. Such treaties can raise specific problems of interpretation owing, inter alia, to their character which is conventional and at the same time institutional". ${ }^{105}$ Again, the law produced by a legal system must possess the same legal nature of its constitutive instrument.

Second, there are some cases in which the issue has been indirectly discussed in relation to law adopted by organizations' organs. For example, the law governing the administration of territories entrusted to international organizations, which is described between its internal and international nature. ${ }^{106}$ The International Court of Justice recognized its dual legality in the Kosovo Advisory Opinion:

\footnotetext{
${ }^{100}$ N Bobbio, Teoria dell'ordinamento giuridico (Giappichelli, 1960).

101 A Rapisardi-Mirabelli, 'Théorie Générale des Unions Internationales' (1925) Recueil des Cours de l'Académie de Droit International de l'Haye 348.

102 S Rosenne, 'Is the Constitution of an International Organization an International Treaty?' (1966) Comunicazioni e Studi (1966) 21.

103 See, inter alia, Alvarez, above n 3, 65; Brölmann, above n 19, 59.

104 Certain Expenses of the United Nations (Article 17, paragraph 2, of the Charter) (Advisory Opinion) [1962] ICJ Rep 151, 157.

${ }^{105}$ Legality of the Use by a State of Nuclear Weapons in Armed Conflict (Advisory Opinion) [1996] ICJ Rep $66,75$.

106 C Stahn, The Law and Practice of International Territorial Administration (Cambridge University Press, 2008); E de Wet, 'The Direct Administration of Territories by the United Nations and its Member States in the Post Cold War Era: Legal Bases and Implications for National Law' (2004) 8(1) Max Planck Yearbook of United Nations Law 291; S Murphy, 'Reflections on the ICJ Advisory Opinion on Kosovo: Interpreting Security Council Resolution 1244 (1999)' in M Milanović and M Wood (eds), The Law and Politics of the Kosovo Advisory Opinion (Oxford University Press, 2015) 134; M Milanović, 'Arguing the Kosovo case' in M Milanović and M Wood (eds), The Law and Politics of the Kosovo Advisory Opinion, (Oxford University Press, 2015) 45; D Jacobs and Y Radi, 'Waiting for Godot: An Analysis of the Advisory Opinion on Kosovo' (2011) 24(2) Leiden Journal of International Law 343.
} 
The Constitutional Framework derives its binding force from the binding character of resolution 1244 (1999) and thus from international law. In that sense it therefore possesses an international legal character. At the same time, the Court observes that the Constitutional Framework functions as part of a specific legal order, created pursuant to resolution 1244 (1999), which is applicable only in Kosovo and the purpose of which is to regulate, during the interim phase established by resolution 1244 (1999), matters which would ordinarily be the subject of internal, rather than international, law. ${ }^{107}$

The international nature has to be assessed looking at the quality of its author (the UNSC) while the internal nature looking at the nature of the act itself. ${ }^{108}$

A third example concerns the nature of peacekeeping operations. Drafting Article 7 of the $A R I O$, Special Rapporteur Gaja notes, "Peacekeeping forces are regarded as subsidiary organs of the United Nations. However, they are made up of State organs, and therefore the question of attribution of conduct is not clear-cut". ${ }^{109}$ For the moment, it is enough to show how under international responsibility peacekeeping missions may be viewed as organs of the organization or state organs. This ambivalence reflects the dual position of member states, which are at the same time organs of the organizations (and the rules are internal law), and third parties (and the rules are international law).

A last example concerns the existence of the so-called objective regimes, treaties that produce obligations for non-parties. ${ }^{110}$ Again, at the core of the problem there is the tension between two poles: collective interest and contractualism. ${ }^{11}$ A concrete case concerns the competence of the International Civil Aviation Organization to regulate air traffic over the high seas. ${ }^{112}$ The rules developed by permanent collective organs may embody the contractual

107 Accordance with International Law of the Unilateral Declaration of Independence in Respect of Kosovo (Advisory Opinion) [2010] ICJ Rep 403, [88]-[89].

108 Stahn, above n 106.

109 G Gaja, Second report on responsibility of international organizations, UN Doc A/CN.4/541 (2 April 2004) [35].

110 M Fitzmaurice, 'Third Parties and the Law of Treaties' (2002) 6(1) Max Planck Yearbook of United Nations Law 37; F Salerno, 'Treaties Establishing Objective Regimes' in E Cannizzaro (ed), The Law of Treaties Beyond the Vienna Convention (Oxford University Press, 2011) 241; S P Subedi, 'The Doctrine of Objective Regimes in International Law and the Competence of the United Nations to Impose Territorial or Peace Settlement on State' (1994) 37 German Yearbook of International Law 174.

111 B Simma, 'The Antarctic Treaty as a Treaty Providing for an Objective Regime' (1986) 19(2) Cornell International Law Journal 189.

112 M Milde, International Air Law and ICAO (Eleven International, 2008); L Weber, International Civil Aviation Organization (Kluwer, 2015); R Abeyratne, 'Law Making and Decision Making Powers of the ICAO Council - A Critical Analysis’ (1992) 41 Zeitschrift fur Luft-und Weltraumrecht 387. 
function between parties and at the same time being customary international law for third parties. ${ }^{113}$

\section{Consequences of the Dual Legality}

Virally described the dual nature of international organizations with the words

cette dualité fondamentale introduit toujours une certaine équivoque dans

l'action institutionnelle: autonome, puisqu'elle se développe suivant ses lois

propres et les décisions prises par les organes de l'institution, elle n'est pas

indépendante, puisqu'elle est téléguidée par les forces qui s'exercent à l'intérieur

de l'institution, mais avec lesquelles celle-ci ne se confond pas. Ainsi l'institution

apparait toujours comme un masque, recouvrant autre chose qu'elle-même.

L'équivoque se dissipe, cependant, lorsqu'on lève le masque et considère le

milieu intérieur qu'il dissimulait. ${ }^{114}$

In order to introduce a framework under which try to understand and resolve the 'ambiguities of the institutional action', the paper will focus on three distinct-but interrelated - issues. First, the law of treaties: how to reconcile the transparent institutional veil of international organizations with the one-dimensional law of treaties? ${ }^{115}$ Second, international responsibility: what is the relationship between member states and organization in the attribution of conduct and responsibility? ${ }^{116}$ Third, invalidity: which is the legal system of reference in order to establish the ultra vires character of an act? ${ }^{117}$ Obviously, there are interconnections between the three topics: the invalidity of a treaty may derive from the invalidity of a rule; the invalidity

113 G Gaja, 'Article 38' in O Corten and P Klein (eds), The Vienna Conventions on the Law of Treaties: A Commentary (Oxford University Press, 2011) 949; P Cahier, 'Le problème des effets des traités à l'égard des états tiers' (1974) 143 Recueil des Cours de l'Académie de Droit International de l'Haye 589.

114 Virally, above n 10,30. (This fundamental duality produces some ambiguity in the institutional action: it is autonomous, since it develops according to its own law and according to the decisions taken by the organs of the institution; but it is not independent, since it is guided by forces that are exercised within the institution, but with which it is not confused. Thus the institution always appears as a mask, covering something other than itself. However, the ambiguity is dissipated when the mask is lifted and the inner-self is revealed.)

115 Brölmann, above n 19.

116 P J Kuijper, 'Introduction to the symposium on Responsibility of International Organizations and of (Member) states: Attributed or Direct Responsibility or Both?’ (2010) 7(1) International Organizations Law Review 9.

117 E Cannizzaro and P Palchetti, 'Ultra Vires acts of international organizations' in J Klabbers and $\AA$ Wallendahl (eds), Research Handbook on the law of international organizations (Edward Elgar, 2011) 365. 
of a rule may also recall responsibility; responsibility may also derive from the breach of a treaty obligation.

\subsection{The Law of Treaties and the Dual Legality of the Rules}

Scholars today do not hesitate to recognize that international organizations have the capacity to conclude treaties. However, the origin of this prerogative and the relationship with the attributed competences are still not clear. ${ }^{118}$ Article 6 of the 1986 Vienna Convention states: "The capacity of an international organization to conclude treaties is governed by the relevant rules of that organization". ${ }^{119}$ The commentary stresses the compromise behind the article, found with the purpose to avoid a clear position on the status of international organizations in international law: "that question remains open, and the proposed wording is compatible both with the concept of general international law as the basis of international organizations' capacity and with the opposite concept". ${ }^{120}$ In analogy with Article 10 of the ARIO, the ILC considered that it could leave the question open. The decision taken by the International Law Commission to avoid a clear reference to the internal law of international organizations is the evidence of the compromise, even if in many provisions the rules are considered equal to states' internal law. ${ }^{121}$

Analyses of early commentators can be roughly ascribed to three schools of thought: the first denies the capacity of organizations to conclude treaties; the second equates this capacity with that of the states; and the third only settles on a limited capacity. ${ }^{122}$ Excluding the idea that international organizations are not able to conclude international agreements, the last two theories reflect the internal and the international nature of the rules. The limited capacity derives from the international nature, while a full capacity, equal to the one possessed by states, derives from the internal nature: "does general international law lay down the principle of such capacity subject to possible limitation by restrictive provisions in constituent instruments, or

\footnotetext{
118 Klabbers, above n 21, 252.

119 For the genesis of Article 6 see J P Dobbert, 'Evolution of the Treaty-Making Capacity of International Organisations' in The Law and The Sea: Essays in Honour of Jean Carroz (FAO, 1987) 21; G Hartmann, 'The Capacity of International Organisations to Conclude Treaties' in K Zemanek (ed), Agreements of International Organisations and the Vienna Convention on the Law of Treaties (Springer, 1971) 127.

120 'Report of the International Law Commission on the work of its thirty-fourth session' [1982] II(2) Yearbook of the International Law Commission 24.

121 G Gaja, 'A 'New' Vienna Convention on Treaties Between States and International Organisations or Between International Organisations: A Critical Commentary’ (1987) 58(1) British Yearbook of International Law 253.

122 P K Menon, The Law of Treaties Between States and International Organisations (Edwin Mellen, 1992) 21.
} 
does capacity derive solely from the rules of particular organizations?"123 The discussion is divided between the objective existence of international organizations, where the capacity is inherent to the organization, ${ }^{124}$ and the will of member states, which have drawn up the constitutive instrument. ${ }^{125}$ Article 6 is an attempt to be consistent with both views and it is based on the definition of the rules of the organization. ${ }^{126}$

The dual legality is at the origin of the transparent institutional veil of the organization and it can explain the position of member states under a treaty signed by an organization. ${ }^{127}$ This was one of the most debated issues faced by the ILC and by the 1986 Vienna Conference: are member states third parties to an agreement concluded by the organization or do they assume rights and obligations? ${ }^{128}$ The troubled history of Article 36bis of the 1986 Vienna Convention explains the difficulties of the question. ${ }^{129}$ Special Rapporteur Reuter identified two different situations in which an agreement may give rise to direct rights and obligations to member states: when the constitutive instrument envisages it or when the internal distribution of competences will produce that effect. ${ }^{130}$ Reuter's proposal moves from the idea of the rules as international law, where third states, concluding an agreement with the organization, are de facto contracting with its member states. After the criticism expressed by the Commission, the

123 F Morgenstern, 'The Vienna Convention on the Law of Treaties between States and International Organisations or between International Organisations' in Y Dinstein (ed), International Law at a Time of Perplexity (Martinus Nijhoff, 1989) 441.

124 F Seyersted, 'International Personality of Intergovernmental Organization' (1964) Indian Journal of International Law 55; Seyersted, above n 17.

125 G Do Nascimento e Silva, 'The 1969 and the 1986 Conventions on the Law of Treaties: A Comparison' in Y Dinstein (ed), International law at a Time of Perplexity, (Martinus Nijhoff, 1989) 461.

126 P Manin, 'La Convention de Vienne sur le droit des traités entre états et organisations internationales ou entre organisations internationales' (1986) Annuaire français de droit international 454.

127 Brölmann, above n 19, 212.

128 C Brölmann, 'The 1986 Vienna Convention on the Law of Treaties: The History of Draft Article 36bis' in J Klabbers and R Lefeber (eds), Essays on the Law of Treaties (Nijhoff, 1998) 121.

${ }^{129}$ N Sybesma-Knol, 'The New Law of Treaties: The Codification of the Law of Treaties Concluded between States and International Organisations or Between Two or More International Organisations' (1985) 15(3) Georgia Journal of International and Comparative Law 425.

130 'Fourth report on the question of treaties concluded between States and international organizations or between two or more international organizations , [1975] II(1) Yearbook of the International Law Commission: 1. A treaty concluded by an international organization gives rise directly for states that are members of an international organization to rights and obligations in respect of other parties to that treaty if the constituent instrument of that organization expressly gives such effects to the treaty. 2 . When, on account of the subject-matter of a treaty concluded by an international organization and the assignment of areas of competence involved in that subject-matter between the organization and its member states, it appears that such was indeed the intention of the parties to that treaty, the treaty gives rise for a member State to: (i) rights, which the member State is presumed to accept, in the absence of any indication of intention to the contrary; (ii) obligations when the member State accepts them, even implicitly. 
Special Rapporteur proposed to give more weight to the autonomy of the organization. ${ }^{131}$ The new proposal is more consistent with an internal nature. The debates around this second proposal concerned whether the provision had a general character or it applied only in the case of the European Union. ${ }^{132}$ The provision included in the draft articles of the ILC is again different: there is not a direct involvement of member states, which instead hide behind the organization. ${ }^{133}$ Here, the internal nature is fully represented and third parties to the agreement assume rights and obligations only with their consent even if they are members of the organization.

The final outcome at the 1986 Vienna Conference was the deletion of the provision, ${ }^{134}$ including only a saving clause in Article 74(3): "The provisions of the present Convention shall not prejudge any question that may arise in regard to the establishment of obligations and rights for States members of an international organization under a treaty to which that organization is a party". This provision does not exclude or confer rights and obligations directly on member states; it simply refers the question to the lex specialis provided by the organization.

The issues arise from the fact that if member states bear rights and obligations, they may have the individual right to present claims and the individual risk of becoming directly subjected to claims. The direct engagement of member states may create an inextricable web of conflicting obligations, allowing non-members to ignore the existence of the internal distribution of rights and obligations. ${ }^{135}$ On the other side of the coin there is the unacceptable

131 'Summary record of the $1510^{\text {th }}$ meeting' [1978] I Yearbook of the International Law Commission 193, [28]: "Third States which are members of an international organization shall observe the obligations, and may exercise the rights, which arise for them from the provisions of a treaty to which that organization is a party if: (a) the relevant rules of the organization, applicable at the moment of the conclusion of the treaty, provide that the States members of the organization are bound by the treaties concluded by it: or (b) the States and organizations participating in the negotiation of the treaty as well as the States members of the organization acknowledged that the application of the treaty necessarily entails such effects".

132 'Summary record of the $1510^{\text {th }}$ meeting' [1978] I Yearbook of the International Law Commission and 'Summary record of the $1512^{\text {th }}$ meeting' [1978] I Yearbook of the International Law Commission 193-203.

133 'Summary record of the $1740^{\text {th }}$ meeting' [1982] I Yearbook of the International Law Commission 252: "Obligations and rights arise for States members of an international organization from the provisions of a treaty to which that organization is a party when the parties to the treaty intend those provisions to be the means of establishing such obligations and according such rights and have defined their conditions and effects in the treaty or have otherwise agreed thereon, and if: (a) the States members of the organization, by virtue of the constituent instrument of that organization or otherwise, have unanimously agreed to be bound by the said provisions of the treaty; and (b) the assent of the States members of the organization to be bound by the relevant provisions of the treaty has been duly brought to the knowledge of the negotiating States and the negotiating organizations".

134 Gaja, above n 121.

135 E Lagrange, La représentation institutionnelle dans l'ordre international: une contribution à la théorie de la personnalité morale des organisations internationales (Brill, 2002) 428. 
idea that organizations are bound by obligations binding member states. ${ }^{136}$ The direct involvement of member states is not a feasible path, since it underlines only the international nature of the rules, in a sort of representation of states made by the organization. The theory does not recognize the autonomy of the organization and the internal nature of the rules. However, member states are not only third parties to the agreements concluded by the organization. Often, the decision to conclude a treaty is taken unanimously by member states and it derives from the sum of their will. Often, international organizations conclude treaties with third parties in order to confer rights to their member states. In this case, they may even confer rights and exclude obligations, as in the case of fishing agreements concluded by the European Union. ${ }^{137}$ Indeed, the International Tribunal for the Law of the Sea recently found that EU member states are not responsible for the conduct of the vessels flying their flag since they are not parties to fishing agreements concluded only by the European Union under its exclusive competence. ${ }^{138}$

The dual legality of the rules may help in considering the indirect position of member states, which are neither parties nor third parties, but still play a role in the treaty concluded by the organization. The legal concept that seems to best represent the position of member states is subsidiarity, which has first found recognition in the context of international responsibility.

\subsection{The Responsibility of International Organizations and the Dual Legality of the Rules}

The dual legality of the rules is consistent with most of the fundamental decisions taken by the ILC in drafting the project on the international responsibility of international organizations. Indeed, other scholars have already described how the Commission modified the nature of the rules throughout the project. ${ }^{139}$ The double standard applied by the International Law Commission is a symptom of the dual nature of the rules, and its acknowledgment helps to understand the nature of the responsibility of international organizations. The immediate effect

\footnotetext{
${ }^{136} \mathrm{C}$ Tomuschat, 'International Organizations as Third Parties under the Law of International Treaties' in E Cannizzaro (ed) The Law of Treaties Beyond the Vienna Convention (Oxford University Press, 2011); F Naert, 'Binding International Organisations to Member State Treaties or Responsibility of Member States for Their Own Actions in the Framework of International Organisations' in J Wouters, E Brems, S Smis, and P Schmitt, Accountability for Human Rights Violations by International Organisations (Intersentia, 2010).

137 L Gasbarri, 'Responsabilità di un'organizzazione internazionale in materie di competenza esclusiva: imputazione e obbligo di risultato secondo il tribunale internazionale del diritto del mare' (2015) Rivista di Diritto Internazionale 911.

${ }^{138}$ Request for an Advisory Opinion submitted by the Sub-Regional Fisheries Commission (Advisory Opinion) (International Tribunal for the Law of the Sea, Case No 21, 2 April 2015).

139 Ahlborn, above n 1.
} 
is that each article dealing with the rules cannot be read implying one perspective only. On the contrary, the commentary to Article $10(2)$ of the $A R I O^{140}$ states that "[b]reaches of obligations under the rules of the organization are not always breaches of obligations under international law". ${ }^{141}$ The dual legality challenges the last sentence, considering that breaches of obligations under the rules are violations of the law produced by the organization's legal system, which is peculiar, as it is at the same time internal and international.

One of the most relevant themes dealing with the transparent institutional veil of international organizations is the attribution of conduct and responsibility. ${ }^{142}$ Catherine Brölmann has recently developed her thesis on the international institutional veil in the context of responsibility, underlining the existence of different degrees of transparency, depending on the context in which organizations act. The dual legality challenges this idea, in the attempt to recognize the unified nature of international organizations. The context, or the legal regime, represents what the last section called a perspective of 'relative legality' and it does not change the degree of transparency of the organization. However, relying on the different degrees of the rule's relative legality has unanticipated effects in the attribution of conduct and responsibility. The dual nature of international organizations is here represented in all its consequences, and the present paper can propose a preliminary study only.

In order to attribute the conduct or the responsibility to an international organization, the ILC provides two main mechanisms. ${ }^{143}$ The first relies on the institutional link based on the internal relationship between the organization and the subject that materially commits the illicit act. The main provision is enshrined in Article 6 of the ARIO, concerning the conduct of the organization's organ or agent. ${ }^{144}$ The second one relies on the factual link based on the external relationship between the organization and the subject who materially commit the illicit act. The

140 ARIO art 10(2):

Paragraph 1 includes the breach of an international obligation that may arise for an international organization towards its members under the rules of the organization.

141 'Draft articles on the responsibility of international organizations, with commentaries' [2011] II(2) Yearbook of the International Law Commission, Commentary to Article 10.

142 C Brölmann, 'Member States and International Legal Responsibility: Developments of the Institutional Veil' (2015) 12(2) International Organizations Law Review 358.

${ }^{143}$ F Messineo, 'Attribution of Conduct' in A Nollkaemper and I Plakokefalos (eds), Principles of Shared Responsibility in International Law (Cambridge University Press, 2014).

144 ARIO art 6:

1. The conduct of an organ or agent of an international organization in the performance of functions of that organ or agent shall be considered an act of that organization under international law, whatever position the organ or agent holds in respect of the organization.

2. The rules of the organization apply in the determination of the functions of its organs and agents. 
main provision is enshrined in Article 7 of the $A R I O$, concerning the effective control possessed by the organization over the conduct of a different subject. ${ }^{145}$

On the one hand, under the institutional criteria member states may be seen as organs, implying the internal nature of the rules that build the organization as a unique international entity. On the other hand, under the factual criteria member states may be seen as third parties and the rules as international law. In the first case, considering member states as organs (and the rules as internal) allows the state to avoid the attribution of conduct, hiding behind the organization. ${ }^{146}$ In the second case, considering member states as third parties (and the rules as international) allows to establish the responsibility of member states. ${ }^{147}$

This assertion can be verified by looking at the two opposite concepts of the rules adopted in two cases before the European Court of Human Rights ('ECtHR'). ${ }^{148}$ In Behrami and Saramati, the Court excluded the responsibility of member states, relying on the ultimate authority and control of the UN Security Council. The judgment is written relying on the implied concept of the rules as internal law, justified by the particular constitutional framework of the international presence in Kosovo. The Court, attributing the conduct to the UN, recognized that "UNMIK was a subsidiary organ of the UN endowed with all-inclusive legislative and administrative powers in Kosovo including the administration of justice". ${ }^{49}$ The Court upheld the thesis that the establishment of UNMIK and KFOR derives from an internal delegation of power coming from the Charter of the United Nations. The ultimate

145 ARIO art 7:

The conduct of an organ of a State or an organ or agent of an international organization that is placed at the disposal of another international organization shall be considered under international law an act of the latter organization if the organization exercises effective control over that conduct.

146 For example, compare: Arab Organization for Industrialization and Ors $v$ Westland Helicopters Ltd (Judgment) (23 October 1987) 80 ILR 622 and Arab Organization for Industrialization and Ors $v$ Westland Helicopters Ltd (Judgment) (19 July 1988) 80 ILR 652; JH Rayner (Mincing Lane) Ltdv Department of Trade and Industry and Ors (Judgment) (24 June 1987) 77 ILR 55; $M$ \& Co v The Federal Republic of Germany (1990) 64 Eur Comm HR 138; Waite and Kennedy v Germany (European Court of Human Rights, Grand Chamber, Application No 26083/94, 18 February 1999); Behrami and Behrami v France and Saramati $v$ France, Germany, and Norway (European Court of Human Rights, Grand Chamber, Application Nos 71412/01 and 78166/01, 2 May 2007); Request for an Advisory Opinion submitted by the Sub-Regional Fisheries Commission (Advisory Opinion) (International Tribunal for the Law of the Sea, Case No 21, 2 April 2015).

147 For example, compare: Westland Helicopters Ltd v Arab Organization for Industrialization and Ors (Interim Award) (5 March 1984) 80 ILR 612; Nada v Switzerland (European Court of Human Rights, Grand Chamber, Application No 10593/08, 12 September 2012); Al-Jedda v the United Kingdom (European Court of Human Rights, Grand Chamber, Application No 27021/08, 7 July 2011).

148 Behrami and Behrami v France and Saramati v France, Germany, and Norway (European Court of Human Rights, Grand Chamber, Application Nos 71412/01 and 78166/01, 2 May 2007); Nada v Switzerland (European Court of Human Rights, Grand Chamber, Application No 10593/08, 12 September 2012).

149 Behrami and Behrami v France and Saramati v France, Germany, and Norway (European Court of Human Rights, Grand Chamber, Application Nos 71412/01 and 78166/01, 2 May 2007) [118]. 
authority and control of the UN is able to create the famous chain of command described in paragraph 135. ${ }^{150}$ The United Nations Mission in Kosovo is a subsidiary organ of United Nations and its internal UN status allows member states to hide behind the institutional veil of the organization.

Conversely, the ECtHR in Nada found Switzerland responsible, relying on the implied international nature of Security Council resolutions. In this case, the Court, with the purpose of disregarding the findings of Behrami and Saramati, stated: "In the present case, by contrast, the relevant Security Council resolutions, especially Resolutions 1267 (1999), 1333 (2000), 1373 (2001) and 1390 (2002), required States to act in their own names and to implement them at national level". ${ }^{151}$ For the Court, states are not acting as organs of the United Nations or under its delegated authority, but with their own international personality. Therefore, the internal rules of Behrami become international law in Nada with the purpose of establishing state responsibility. The international nature breaks the chain of command.

The dual legality of the rules may help to enhance a form of shared responsibility between the two entities. ${ }^{152}$ It prompts the consideration of the dual role of member states, as both organs and third parties. On the one hand, the member state cannot hide behind the institutional veil of the organization considered as an internal organ; on the other hand, the organization cannot hide behind the international conduct of the member state considered as a third subject. The general rule on attribution of conduct to an international organization (enshrined in Article 6 of the $A R I O$ ) is able to cover both the exigencies; while the effective control established by Article 7 of the $A R I O$ represents the need to distinguish between primary and secondary responsibility. The outcome of the dual legality is not to establish indiscriminate joint and several liability, but to recognise the existence of two forms of responsibility. The nature of a secondary, or subsidiary, form of responsibility has been developed in the ILC Articles in those provisions dealing with the position of member states with respect to the responsibility of the organization. In particular, Article 40(2) envisages the exigency to ensure the fulfilment of the

\footnotetext{
150 "The UNSC was to retain ultimate authority and control over the security mission and it delegated to NATO (in consultation with non-NATO member states) the power to establish, as well as the operational command of, the international presence, KFOR. NATO fulfilled its command mission via a chain of command (from the NAC, to SHAPE, to SACEUR, to CIC South) to COMKFOR, the commander of KFOR. While the MNBs were commanded by an officer from a lead TCN, the latter was under the direct command of COMKFOR. MNB action was to be taken according to an operational plan devised by NATO and operated by COMKFOR in the name of KFOR".

151 Nada v Switzerland (European Court of Human Rights, Grand Chamber, Application No 10593/08, 12 September 2012) [120].

152 A Nollkaemper and I Plakokefalos (eds), Principles of Shared Responsibility in International Law (Cambridge University Press, 2014).
} 
obligation to make reparation. ${ }^{153}$ Differently from what Ian Brownlie proposed within the International Law Commission, member states are not automatically responsible for the illicit conduct of the organization. ${ }^{154}$ The thesis is based on the idea of international organizations as purely transparent entities, relying on the extreme consequences of the international nature of the rules.

\subsection{The Validity of the Rules of International Organizations and Their Dual Legality}

The validity of the rules is the last topic that this paper will address. ${ }^{155}$ Again, this paper will only introduce the opportunity to look at the issue from the perspective of the nature of the rules. The issue comes with a number of fundamental questions that can be divided in three main categories: the parameters of the validity (which is the legal system of reference?); the subjects with the power to claim invalidity (who is the ultimate judge over the acts of the organization?) and the consequences of invalidity (between ex tunc and ex nunc effects). ${ }^{156}$

This section will focus on the first question only. It will discuss the formal validity of norms starting from a positivist perspective. ${ }^{157}$ The formal validity is related to a norm belonging to a legal system of reference, and it is based on the respect of the parameters imposed by that system. It follows the principle of hierarchy, under which the inferior norm must be in accordance with the superior. ${ }^{158}$

Concerning the rules of international organizations, the concept of validity interferes with the concept of ultra vires acts. ${ }^{159}$ The notion of ultra vires refers to acts of an international organization taken beyond its competences, which causes their invalidity. Again, the issue is divided between the dichotomy of competence and capacity.

In the few cases in which the International Court of Justice was called to assess the validity of a rule, it always struggled to find a balance between the two faces of international

${ }^{153}$ ARIO art 40(2):

2. The members of a responsible international organization shall take all the appropriate measures that may be required by the rules of the organization in order to enable the organization to fulfil its obligations under this Chapter.

${ }^{154}$ P Palchetti, 'Exploring Alternative Routes: the Obligation of Members to Enable the Organization to Make Reparation' in M Ragazzi (ed), Responsibility of International Organizations (Brill, 2013) 303.

${ }^{155} \mathrm{R}$ Bernhardt, 'Ultra Vires Activities of International Organizations' in Theory of International Law at the Threshold of the 21st Century (Kluwer, 1996) 599.

${ }^{156}$ E Osieke, 'The Legal Validity of Ultra Vires Decisions of International Organizations' (1983) 77(2) The American Journal of International Law 239.

157 van de Kerchove and Ost, above n 95, 270.

${ }^{158}$ Kelsen, above $\mathrm{n} 92$.

${ }^{159}$ Cannizzaro and Palchetti, above n 117. 
organizations. When the Court recognizes the validity of a rule, it does so looking at the internal legal system of the organization and to its autonomy from member states. ${ }^{160}$ For example, in the Certain Expenses Advisory Opinion, the Court looked at the purposes of the United Nations: "such expenditures must be tested by their relationship to the purpose of the United Nations in the sense that if an expenditure were made for a purpose which is not one of the purposes of the United Nations, it could not be considered an 'expense of the Organization"'. ${ }^{161}$ Conversely, when the Court recognizes the invalidity of a rule, it does so looking at the international nature of the rule and to its functionalist origin limited by the competences given by member states. ${ }^{162}$ For example, in Legality of the Use by a State of Nuclear Weapons in Armed Conflict, the Court interpreted the WHO Constitution using the tools provided by the law of treaties and applying a strict functionalism approach:

The Court need hardly point out that international organizations are subjects of international law which do not, unlike States, possess a general competence. International organizations are governed by the 'principle of speciality', that is to say, they are invested by the States which create them with powers, the limits of which are a function of the common interests whose promotion those States entrust to them. ${ }^{163}$

The two faces of international organizations emerge in all their effects in the Interpretation of the Agreement of 25 March 1951 between the WHO and Egypt Advisory Opinion. ${ }^{164}$ In order

\footnotetext{
${ }^{160}$ For example, compare: Interpretation of the Convention of 1919 concerning Employment of Women during the Night (Advisory Opinion) [1932] PCIJ (ser A/B) No 50; Competence of the ILO in regard to International Regulation of the Conditions of the Labour of Persons Employed in Agriculture (Advisory Opinion) [1922] PCIJ (ser B) No 2; Competence of the ILO to Examine Proposal for the Organization and Development of the Methods of Agricultural Production (Advisory Opinion) [1922] PCIJ (ser B) No 3; Competence of the ILO to Regulate Incidentally the Personal Work of the Employer (Advisory Opinion) [1926] PCIJ (ser B) No 13; Certain Expenses of the United Nations (Article 17, paragraph 2, of the Charter) (Advisory Opinion) [1962] ICJ Rep 151, 167; Legal Consequences for States of the Continued Presence of South Africa in Namibia (South West Africa) notwithstanding Security Council Resolution 276 (1970) (Advisory Opinion) [1971] ICJ Rep 16; Legal Consequences of the Construction of a Wall in the Occupied Palestinian Territory (Advisory Opinion) [2004] ICJ Rep 136.

161 Certain Expenses of the United Nations (Article 17, paragraph 2, of the Charter) (Advisory Opinion) [1962] ICJ Rep 151, 167.

162 For example, compare: Constitution of the Maritime Safety Committee of the Inter-Governmental Maritime Consultative Organization (Advisory Opinion) [1960] ICJ Rep 150; Legality of the Use by a State of Nuclear Weapons in Armed Conflict (Advisory Opinion) [1996] ICJ Rep 66.

163 Legality of the Use by a State of Nuclear Weapons in Armed Conflict (Advisory Opinion) [1996] ICJ Rep $66,[25]$.

164 Interpretation of the Agreement of 25 March 1951 between the WHO and Egypt (Advisory Opinion) [1980] ICJ Rep 73.
} 
to discuss the issue, one of the most interesting concrete circumstances in which an alleged ultra vires character has been claimed concerned the anti-terrorism sanctions taken by the UN Security Council in relation to human rights standards. ${ }^{165}$ This last example will conclude this paper, closing the circle opened at the beginning. Validity must be ascertained looking at the legal system to which the act belongs. Following the dual legality of the rules, it must derive from the constitutive instruments (and other hierarchically superior internal rules) and from general international law. The dual legality of ultra vires acts is something already acknowledged, at least implicitly. ${ }^{166}$ It arises from the constitutional perspective of the organization, where the legality of its acts (seen as internal law) must be assessed in conformity with the constitutive treaty, ${ }^{167}$ and from the international perspective, where the illegality of the acts must be assessed in conformity with international law. ${ }^{168}$

The dual legality may help to explain how international organizations are at the same time bound by their internal lex specialis and by general international law. As to the United Nations and human rights obligations, the first claim is made looking at the Charter of the United Nations as a limit to UN Security Council resolutions. ${ }^{169}$ Following this approach, the rules are seen as internal law of the $\mathrm{UN}$, and the regime of reference is constituted by its lex specialis, which provides the limits of the Security Council's powers. ${ }^{170}$ Following this path, the problem is to reconcile the UN's purpose to promote and encourage the respect of human rights by its member states with the existence of a legal obligation binding the UN itself. ${ }^{171}$ The second criterion of legality derives from general international law. ${ }^{172}$ As the International Court of Justice famously stated in the Interpretation of the Agreement of 25 March 1951 between the WHO and Egypt Advisory Opinion, "International organizations are subjects of international law and, as such, are bound by any obligations incumbent upon them under

\footnotetext{
165 A Ciampi, Sanzioni del Consiglio di sicurezza e diritti umani (Giuffré, 2007).

166 Cannizzaro and Palchetti, above n 117, 390.

167 B Conforti, 'The Legal Effect of Non-Compliance with Rules of Procedure in the UN General Assembly and Security Council' (1969) 63(3) America Journal of International Law 479.

168 K Doehring, 'Unlawful Resolutions of the Security Council and their Legal Consequences' (1997) 1(1) Max Planck Yearbook of United Nations Law 91.

${ }^{169}$ E de Wet, The Chapter VII Powers of the United Nations Security Council (Hart Publishing, 2004).

170 A Tzanakopoulos, Disobeying the Security Council: Countermeasures against Wrongful Sanctions (Oxford University Press, 2011) 57.

${ }^{171}$ I Johnstone, 'The UN Security Council, Counterterrorism and Human Rights' in A Bianchi and A Keller (eds), Counterterrorism: Democracy's Challenge (Hart Publishing, 2008); A Bianchi, 'Anti-terror resolutions and their Implementation by Member States: an Overview' (2006) 4(5) Journal of International Criminal Justice 1044.

172 Ciampi, above n 165, 141.
} 
general rules of international law, under their constitutions or under international agreements to which they are parties". ${ }^{173}$ Therefore, customary human rights may hypothetically bind international organizations. However, there is at least one problem with this argument, and the dual legality of the rules may be helpful in resolving it. The lex specialis character of the Charter of the United Nations may allow derogation from general international law. ${ }^{174}$ Thus, every Security Council resolution may derogate from customary law, imposing its nature of international law. Notwithstanding, the contextual internal nature of the resolutions may prevent the possibility of such derogation. Indeed, resolutions are not only international law and they derive their legality from the Charter of the United Nations. It is the Charter of the United Nations that may derogate from general international law, not the resolution. ${ }^{175}$ Recognizing the absence of a provision in the Charter of the United Nations that consents to derogations from human rights obligations, the dual legality of Security Council resolutions may support their invalidity in case of violations.

The rules of international organizations have internal and international criteria of validity, allowing reconciliation between lex specialis and lex generalis. ${ }^{176}$ Their parallel application is the possible outcome of the dual legality of the rules.

\section{$5 \quad$ Conclusion}

This paper argued that every rule of every international organization must share the same nature, without indulging in theories that rely on different degrees of legality. Using tools provided by analytical jurisprudence, the nature of the rules has been described as harmonizing an internal and an international nature. The dual legality of the rules has been compared with some questions arising from the law of treaties, international responsibility and invalidity for ultra vires acts, in order to provide a theory that could harmonize the two faces of international organizations. After all, already in 1963 the European Court of Justice affirmed: "the Community constitutes a new legal order of international law". ${ }^{177}$

\footnotetext{
173 Interpretation of the Agreement of 25 March 1951 between the WHO and Egypt (Advisory Opinion) [1980] ICJ Rep 73, 89-90.

174 Ciampi, above n 165, 142.

${ }^{175}$ D Akande, 'The International Court of Justice and the Security Council: Is there Room for Judicial Control of Decisions of the Political organs of the United Nations?' (1997) 46(2) International and Comparative Law Quarterly 309.

176 Tzanakopoulos, above n 170, 57.

177 van Gend \& Loos v Nederlandse Administratie der Belastingen (European Court of Justice, Case 26/62, 5 February 1963) 12.
} 
Different regimes or different international organizations may rely on the complex institutional nature in order to achieve the desired outcome, wherever it means to exclude responsibility or demonstrate the validity of acts. This is evident in the context of UN Security Council anti-terrorist resolutions. The United Nations may adopt different institutional veils in order to achieve different outcomes. ${ }^{178}$

On the one hand, if resolutions are purely international law, it is difficult to sustain that the UN is bound by human rights obligations, even considering its lack of capacity to possess jurisdiction. ${ }^{179}$ On the other hand, if resolutions are purely internal law, it is difficult to sustain that individuals possess legal personality within the particular UN legal system, even considering that invalidity may encounter only internal criteria.

The dual legality of the rules is an attempt to acknowledge the transparency of the institutional veil excluding the existence of different degrees. The autonomy possessed by international organizations does not allow states to disappear behind the organization and their indirect role should find a proper legal concept.

178 L Gasbarri, 'In difesa del Consiglio di sicurezza: violazioni dei diritti umani e lotta al terrorismo' in A. Spagnolo and S. Saluzzo (eds), La responsabilità degli Stati e delle organizzazioni internazionali: nuove fattispecie e problemi di attribuzione e di accertamento, (Ledizioni, forthcoming 2017).

179 S Besson, 'The Bearers of Human Rights' Duties and Responsibilities for Human rights: A Quiet (R)evolution?’ (2015) 32(1) Social Philosophy and Policy 244. 